e-ISSN: 2550-1313 | p-ISSN: 2087-9849

http://jurnal.fkip.unila.ac.id/index.php/jpp/

\title{
Principal Strategy in Improving Teacher Performance to Achieve Learning Effectiveness at Public Middle School in Banda Aceh City
}

\author{
Suci Natasya Chairi, Cut Zahri Harun*, Nasir Usman \\ Department of Education Administration, Syiah Kuala University, Indonesia \\ *Coresponding email: profcut@unsyiah.ac.id
}

Received: 27 October 2019

Accepted: 21 July 2020

Published: 25 November 2020

Abstract: Principal Strategy in Improving Teacher Performance to Achieve Learning Effectiveness at Public Middle School in Banda Aceh City. Objectives: The aim of this research is to obtain complete and accurate data from the school about principal strategy in improving the learning effectiveness. Methods: This research used decriptive qualitative approach. The technique of data collection used are observation, interview, and documentation. The subject of this research are principals, and teachers. Findings: The result of this research shows that: (1) Principal strategy in the process of program arrangement are creating the team to arrange the program, to build disipline, to make employment contract, to motivate, to training and supervision; (2) The principal in implementing the coaching and development program to improve the learning effectiveness, the principal controlled the program implementation in order to be implemented well; (3) Principal strategy in evaluating the coaching and development program to improve the learning effectiveness is by doing evaluation.

Keywords: Principal strategy, teacher performance, learning effectiveness.

Abstrak: Strategi Kepala Sekolah dalam Meningkatkan Kinerja Guru untuk Mencapai Efektivitas Belajar di Sekolah Menengah Umum di Kota Banda Aceh.Tujuan: Tujuan dari penelitian ini adalah untuk memperoleh data yang lengkap dan akurat dari sekolah tentang strategi kepala sekolah dalam meningkatkan efektivitas belajar. Metode: Penelitian ini menggunakan pendekatan kualitatif deskriptif. Teknik pengumpulan data yang digunakan adalah observasi, wawancara, dan dokumentasi. Subjek penelitian ini adalah kepala sekolah, dan guru. Temuan: Hasil penelitian ini menunjukkan bahwa (1) Strategi utama dalam proses pengaturan program adalah menciptakan tim untuk mengatur program, membangun disiplin, membuat kontrak kerja, memotivasi, mengikuti pelatihan dan pengawasan; (2) Kepala sekolah dalam melaksanakan program pembinaan dan pengembangan untuk meningkatkan efektivitas belajar, kepala sekolah mengendalikan pelaksanaan program agar dapat dilaksanakan dengan baik; (3) Strategi utama dalam mengevaluasi program pembinaan dan pengembangan untuk meningkatkan efektivitas pembelajaran adalah dengan melakukan evaluasi.

Kata kunci: Strategi kepala sekolah, kinerja guru, efektivitas belajar.

\section{To cite this article:}

Chairi, S. N., Harun, C. Z., \& Usman, N. (2020). Principal Strategy In Improving Teacher Performance To Achieve Learning Effectiveness At Public Middle School In Banda Aceh City. Jurnal Pendidikan Progresif, 10(3), 492-499. doi: 10.23960/jpp.v10.i3.202011. 


\section{INTRODUCTION}

Leadership of learning is the principal action for the aim to develop a productive and satisfy the work environment of the teachers, and at the end able to develop learning conditions and manage a learning environment that enables to improve student learning achievement and increase learning effectiveness (MacBeath, 2019; Tsai et.al., 2019; Cook \& Felten, 2017; Baker, 2017). The principal as a leader of education is a leadership that focuses on the realm of learning, including curriculum, teaching and learning processes, evaluation or assessment, teacher development, excellent service in learning process, and development of learning communities in the school (Fuller \& Templeton, 2019; Knight, 2019; Fiori, 2018; Hejres, Braganza, \& Eldabi, 2017).

The principal successful if the principal understand the existence of the school as a complex and unique organization and able to carry out the role of the principal as someone who is a leader in the school. The study of the principal's success shows that the principal is someone who determines the center and rhythm of a school (Johnson, Pas, \& Bradshaw, 2016; Klar et.al., 2016;Zhang \& Pang, 2016). The principal is a leader who is an influence in carrying out his role as a leader learning. Principal is a leader or a driver of education in school must be able to search, to find, and to implement various reforms in school, that include to search and to find the ways for develop the teacher creativity, and makes learning becomes more attractive and learning becomes more effective(Glatthorn, Jailall, \& Jailall, 2016; Li, Hallinger, \& Ko, 2016).

Teacher as professional teaching staff with the main task are educating, teaching, guiding, directing, training, assessing and evaluating students in formal education that in the elemantery or in junior high school student (Matherson \& Windle, 2017; Ping, Schellings, \& Beijaard,
2018). The teacher is implementing education in school that directly interact with students are very important competencies in the Teaching and Learning Process. The learning is success that depends on teacher's creativity in teaching performance (Cheng, 2018; Mayes, 2018). The creativity is influences to the success of work. The work success are influenced by several factors including the mental, attitude, education, skills, management, income level, nutrition and health, social security, environment and work climate, production facilities, technology and opportunities for achievement. Indirectly the teacher's creativities that impact to the effectiveness of student's learning. If the teacher's creativities is high, the effectiveness of student's learning is also increase. it means that the teacher's creativity has a role in increasing the student's learning effectiveness, and can print qualified graduates in terms of academics and morals in order to be able to compete in this era of globalization (Huang, Lee, \& Yang, 2019; Cayirdag, 2017).

Educators must have academic qualifications and competencies as agents of learning, physically and mentally healthy and have the ability to realize national education goals. As mandated in the article, that mean the educators as agents of learning (learning agents) in this provision is the role of educators as facilitators, motivators, boosters, and learning inspirers for students (Altbach, Reisberg, \& Rumbley, 2019; Czerniawski, Guberman, \& MacPhail, 2017). Based on the education regulation quote, it can be clearly understood that the education process and learning in any educational unit, in a formal juridical manner must be held creatively to create an impressive and meaningful atmosphere for the student, so learning becomes more effective, and can improve learning effectiveness. The ability to think creative are needed to improve the quality of schools, but in reality not all schools are aware 
about the importance of creativity. Creativity is not born only by chance but through a series of processes that require strong perseverances, skills and motivations (Paul \& Elder, 2019).

Looking at the school institutions that exist at the present time, there are many people who can't improve their creativity. As the results of preliminary study at several junior high schools in Banda Aceh, there were teachers with lack of the motivation to develop their competence in teaching, The teachers are less creative in managing teaching materials, lack of teacher skills in using science and technology, teachers tend to use monotonous and non-creative methods, teachers are only stunned to use the printed of books that make learning unattractive, and very boring, and makes student become lazy to learn and can't to develop, and makes the learning process becomes in effective.

The success of developing creativity is determined by the principal leadership. The principal as the key to opening the quality of the school. During the time learning only focuses on one direction only the teacher gives material and students are required to listen to the explanation, and write the material provided.The principal's strategy is very important in regulating teaching and learning activities to increase teacher creativity in the learning process. Besides that, the principal is also directly responsible for the implementation of all types and forms of regulations or rules that must be carried out by the teacher and by the students (Mehta, Xu, \& Dahl, 2019). Effectiveness is the suitability of an organization's activities towards the objectives to be achieved, in accordance with a specified work. Effectiveness is the relationship between output and purpose, in terms of effectiveness is a measure of how far the level of output, the policy of the organization in achieving its intended purpose (Choi, Kim, \& Kang, 2017). Based on the aforementioned theoretical background, the principal's strategy is very important to make the education running wheel. Thus the importance of developing the quality of teacher performance in improving student learning outcomes, the development of teacher creativity in teaching is one of the urgent choices to be implemented in achieving learning effectiveness.

\section{METHODS}

This research used a descriptive qualitative approach that is intended to investigate the circumstances, conditions, or other things what results are presented in the form of research reports. A qualitative approach emphasizes the elaboration of concepts. Qualitative research is research that produces the findings there are not achieved by using statistical procedures or by means of quantification. The purpose of qualitative research is to describe and analyze phenomena, events, social activities, attitudes, beliefs, perceptions, thoughts of a person or group and some descriptions to find principles and explanations that lead to conclusions that are inductive in nature. effectiveness of learning. With these concepts, it will be reviewed and discussed into more useful data.

The subject of this research is the subject that we will examine. The subject of research is the subject that the researcher aim to do the research, that become the center of observation or the target of the researcher. The subjects in this study were principals and teachers, to find out the principal's strategy in improving the effectiveness of learning in the State of Junior High School in Banda Aceh. Especially for State Junior High School 10 Banda Aceh, State Junior High School 16 Banda Aceh, State Junior High School 18 Banda Aceh. This study using the research instrument in the form of interview guides, observation guidelines, and documentation guidelines. 


\section{- RESULT AND DISCUSSION}

A. The Process of Planning ProgramTeacher Coaching and Development to Improve Learning Effectiveness at State Junior High Schools in Banda Aceh Municipality

The planning process of the program that occurs in State Junior High Schools 10 Banda Aceh, State Junior High Schools 16 Banda Aceh, and State Junior High Schools 18 Banda Aceh, after conducting research, the researchers found the results of the study that: the principal's strategy in the planning and development program to improve learning effectiveness with making the work meetings to compile the program and to make a team that consisting of the vice curriculum, The vice of students and teaching staff to discuss the problems that appear in all this time and together find the solutions, together they can arranging programs, then the wisdom are implemented. It is expected that the planning of this program will run according to what is expected to achieve educational goals in accordance with the 8 predetermined educational standards. Planning is prepared by considering the overall needs of the school organization. Units that exist within the school organization up to individuals, unite vision, mission, to improve performance unite and harmonize goals with existing organizational strategies to achieve goals organization. The preparation of this program was compiled during the work meeting held at the beginning of the learning year, not only the principal and all personnel involved in the preparation of this program but the team brought in from the agency also helped to arrange the school program.

The principal's strategy in developing the effectiveness of school learning is also by implementing the wisdom, such as applying discipline to each citizen of school, especially teachers who are direct implementers of the learning process, examining teacher learning devices at the beginning of the year, making work contracts with teachers, then motivating teachers, conducting the training to improve teacher competency in teaching, encourage teachers to develop their creativity to maximize the school facilities and infrastructure for maximize the learning process, and conduct supervision to see teacher development. The principal's strategy is very important in improving the quality of education in schools that can improve teacher performance and also maximize learning. School principals must carry out the following roles. First; involving teachers in upgrading to broaden the teacher's insight. The principal must also provide opportunities for teachers to improve their knowledge and skills by learning to a higher level. Second; the principal must try to move the student learning outcomes evaluation team to work more actively, then the results are announced publicly and shown on the bulletin board. Third; use learning time effectively at school, by encouraging teachers to start and end learning according to a predetermined time, and to use it effectively and efficiently for the benefit of learning.

The training program was also held by the principal of the State Junior High School in Banda Aceh City in order to improve the effectiveness of Learning by holding regular monthly meetings in an effort to improve teacher performance, holding training in the school by inviting instructors from outside to provide useful material to improve teacher competency in teaching, such as inviting instructors from the city or provincial service, from unsyiah, from Erlangga publishers and others. Another effort to improve teacher performance that if there is training conducted outside of the school, the principal provides motivation to the teacher to attend training for teacher selfdevelopment, such as MGMP training, training in accordance with their respective fields of study. Including teacher training, training and seminars aims that teachers add new insights and 
innovations in accordance with increasingly advanced technological capabilities and an increasingly developing education system. With including teachers in training development can improve teacher competence in teaching which is will improve the quality of the learning process in school.

B. The Process of Implementation Teacher Coaching and Development Program to Improve Learning Effectiveness at State Junior High School in BandaAceh Municipality

The implementation of this program was to implement a program that had been prepared at the beginning of the learning year, the implementation of the programs carried out in The planning process of the program that occurs in State Junior High Schools 10 Banda Aceh, State Junior High Schools 16 Banda Aceh, and State Junior High Schools 18 Banda Aceh according to the research results obtained at the three schools. The implementation of the program has been running in accordance with the program that has been prepared, but in its implementation there are several obstacles that make the implementation must not be in accordance with the plan.

The principal is a leader who moves all school components to maximize performance and all resources to achieve the educational goals of the school he leads, the principal is responsible for the running of the program in accordance with the plans that have been made, maximizing the work program by conducting training and teacher training. The implementation of activities is the realization of programs that have been prepared before. The principal has responsibility in managing the education process to educate student who work with education staff(teachers) implementation of training programs. The principal conducts training and coaching by inviting instructors from outside to improve the learning effectiveness in the school that is led, if the principal is absent, if there is a busy schedule outside the school organized by the education office, the principal has authorized the vise curriculum to monitor the implementation the program to run optimally.

There are several requirements created to create an effective training, namely: Training programs are based on the needs or problems faced by organizations or companies, training programs are based on goals or competencies the training program participants need, the schedule for organizing the training program is well organized, the program participants' backgrounds are in accordance with the competency of the program to be trained, the instructors have good qualifications and are competent in the practiced field, the training is carried out in a comfortable place with supporting facilities sufficient, the training program is able to facilitate so that participants have the necessary competencies, the training program must be able to give satisfaction to the program participants, the training program needs to be evaluated on an ongoing basis.

C. Evaluation of Teacher Coaching and Development Programs to Improve Learning Effectiveness at State Junior High School in Banda Aceh Municipality

The strategy of the The planning process of the program that occurs in State Junior High Schools 10 Banda Aceh, State Junior High Schools 16 Banda Aceh, and State Junior High Schools 18 Banda Aceh, program evaluation was carried out at the end of the training to determine the progress of the teacher after the training, to find out how the changes occurred after the training program was implemented. This evaluation is conducted to determine the success of a program that has been made, and to make the program better in the future. Training evaluation compares the results after training to the objectives expected by managers, trainers, and 
participant traning. Too often doing training but not measuring and evaluating it is a waste because training takes time and costs a lot. Educational evaluation is to obtain evidence data that will show where the level of ability and success of students in achieving learning goals.

Evaluation is carried out to see the whole learning process in order to find out how the ability of the teacher, can be seen during the implementation of supervision carried out regularly twice a year. there are two kinds of supervision activities, namely: summative and normative supervision, namely normative supervision and normative supervision. If there are deficiencies in vormative supervision, then improvement and guidance are carried out on summative supervision. Supervision functions to coordinate, stimulate, and direct the growth of teachers; coordinating all school efforts, equipping school leadership, broadening the experience of teachers, stimulating creative endeavors, providing facilities and continuous assessment, analyzing teaching and learning situations, providing knowledge and skills to teachers and staff, integrating educational goals and helping to improve skills teacher. Follow-up to carried out on summative supervision is very important, because the teacher must to know the strengths and weaknesses of each, so they know things that need to be maintained, and which is needs to be optimized again in the learning process and makes that learning is more effective and efficient.

D. The Strategy of Principal in Improving Teacher Performance to Achieve Learning Effectiveness at Public Middle Schools in Banda Aceh City

The results of the research that the researchers obtained were in State Junior High Schools 10 Banda Aceh, State Junior High Schools 16 Banda Aceh, and State Junior High Schools 18 Banda Aceh after conducting research, there were several obstacles in the implementation of the program which hampered the implementation of the program, namely the obstacles that principal confront on implementation of training, the principal is called to attend meetings held outside the school so that the principal cannot monitor the course of the training carried out in the school, but the principal gives authority to the vice of curriculum to monitor the course of the training program for it runs well.

A lot of effort made by the principal to overcome these problems, to improve teacher performance to hold meetings, make training to improve the teacher's ability little by little even though that step by step, doing supervise, establish communication with teachers to found problems can and found the solutions, and then entered into a work contract at the beginning of the year, so the teachers who are not disciplined in the future will be sanctioned that will not be given 24 hours of school hours. Then the students confornt some problems such as family background problems, principals make meetings with student guardians to establish good communication with student guardians, work together to realize the best education for students, and to raise awareness that the support from parents is very influential to increase student achievement. The Higher involvement of parents, that the higher the motivation to learn, and the higher the learning achievement, and vice versa, the lower the involvement of parents, the lower the motivation to learn the lower learning achievement.

\section{CONCLUSION}

This study, it can be concluded that the strategy of the school principal in the process of preparing teaching coaching and development programs to improve learning effectiveness in the State Junior High School in Banda Aceh City is to form arranging team at a work meeting consisting of vice curriculum and vise of students, discussing about the problems confornt so far 
can make improvements, make the wisdoms, make work contracts, implement teacher discipline, arrange training and coaching programs, and arrange supervision schedules. The strategy of the principal in implementing teacher coaching and development programs to improve the learning effectiveness is to conduct training and coaching in schools by inviting instructors from outside, untill all teachers in the school can attend training to develop their potential, and the principal motivates to the teacher to attend training in which held by the education office based on their competencies and fields of study.

The principal's strategy in evaluating the teacher coaching and development programs to improve the learning effectiveness is evaluation conducted at the end of the training program, evaluation doing to determine the level of program achievement to the objectives set, evaluation is also to carried out to get pay attention all components involved in the training, and whether the availability of infrastructure facilities has supported the training program, the discipline teachers in participating with the training program, evaluating the development after attending the development training is there better after participating in the program so that the training program implementation will be better in the future. Constraints faced by the principal in effort to increase the effectiveness of learning in the State Junior High School in Banda Aceh City are the existence of undisciplined teachers, teachers who are less responsible for their duties such as careless in making the questions, then obstacles that come from students, students do not want learning, do not want paid attention to the teacher, being disrespectful towards the teacher, and lack of parental attention to the child that makes the students are not motivated to learn, even though parental support is very influential on children's achievement. The principal as a motivator, has tried to provide motivation for students, teachers, and hold meetings with guardians of students with the aim of establishing good relationships with parents of student guardians, while providing awareness to guardians of students to pay attention to and support student education, because of parents' support on children's education is very influential on student achievement.

\section{REFERENCES}

Altbach, P. G., Reisberg, L., \& Rumbley, L. E. (2019). Trends in global higher education: Tracking an academic revolution. Brill.

Baker-Doyle, K. J. (2017). Transformative Teachers: Teacher Leadership and Learning in a Connected World. Harvard Education Press. 8 Story Street First Floor, Cambridge, MA 02138.

Cayirdag, N. (2017). Creativity fostering teaching: Impact of creative self-efficacy and teacher efficacy. Educational Sciences: Theory \& Practice, 17(6).

Cheng, V. M. (2018). Consensual assessment of creativity in teaching design by supportive peers: Its validity, practicality, and benefit. The Journal of Creative Behavior, 52(1), 5-20.

Choi, S. B., Kim, K., \& Kang, S. W. (2017). Effects of transformational and shared leadership styles on employees' perception of team effectiveness. Social Behavior and Personality: an international journal, 45(3), 377-386.

Cook-Sather, A., \& Felten, P. (2017). Ethics of academic leadership: Guiding learning and teaching. Cosmopolitan perspectives on academic leadership in higher education, 175-191.

Czerniawski, G., Guberman,A., \& MacPhail, A. (2017). The professional developmental needs of higher education-based teacher 
educators: An international comparative needs analysis. European Journal of Teacher Education, 40(1), 127-140.

Fiori, B. K. (2018). School Principal as Instructional Leader: Connections Between Principal Evaluation and Student Achievement (Doctoral dissertation, University of Dayton).

Fuller, M. J., \& Templeton, N. R. (2019). Principal as Servant-Leader: An Embedded-Descriptive Single-Case Study of One Prekindergarten School's Efforts to Build Teacher Capacity in Foundational Skills. Education Leadership, 190.

Glatthorn, A. A., Jailall, J. M., \& Jailall, J. K. (2016). The principal as curriculum leader: Shaping what is taught and tested. Corwin Press.

Hejres, S., Braganza, A., \& Eldabi, T. (2017). The impact of Acceptance of Leader criteria on Instructional Leadership. Educational Research Application, 10, 2575-7032.

Huang, X., Lee, J. C. K., \& Yang, X. (2019). What really counts? Investigating the effects of creative role identity and selfefficacy on teachers' attitudes towards the implementation of teaching for creativity. Teaching and Teacher Education, 84, 57-65.

Johnson, S. L., Pas, E., \& Bradshaw, C. P. (2016). Understanding the association between school climate and future orientation. Journal of youth and adolescence, 45(8), 1575-1586.

Klar, H. W., Huggins, K. S., Hammonds, H. L., \& Buskey, F. C. (2016). Fostering the capacity for distributed leadership: A postheroic approach to leading school improvement. International Journal of Leadership in Education, 19, 111-137.

Li, L., Hallinger, P., \& Ko, J. (2016). Principal leadership and school capacity effects on teacher learning in Hong Kong. International Journal of Educational Management.

Knight Abowitz, K. (2019). The school principal as democratic leader: A critique of the Wallace Foundation's vision of the principalship. International Journal of Leadership in Education, 1-7.

MacBeath, J. (2019). Leadership for learning. In Instructional Leadership and Leadership for Learning in Schools (pp. 49-73). Palgrave Macmillan, Cham.

Matherson, L., \& Windle, T. M. (2017). What do teachers want from their professional development? Four emerging themes. Delta Kappa Gamma Bulletin, 83(3), 28.

Mayes, T. (2018). Learning technology and learning relationships. In Teaching \& learning online (pp. 16-26). Routledge.

Mehta, R., Xu, L., \& Dahl, D. W. (2019). The role of identity salience in creative thinking. In Handbook of Research on Identity Theory in Marketing. Edward Elgar Publishing.

Paul, R., \& Elder, L. (2019). The nature and functions of critical $\&$ creative thinking. Rowman \& Littlefield.

Ping, C., Schellings, G., \& Beijaard, D. (2018). Teacher educators' professional learning: Aliterature review. Teaching and Teacher Education, 75, 93-104.

Tsai, Y. S., Poquet, O., Gaševiæ, D., Dawson, S., \& Pardo, A. (2019). Complexity leadership in learning analytics: Drivers, challenges and opportunities. British Journal of Educational Technology, 50(6), 2839-2854.

Zhang, J., \& Pang, N. S. K. (2016). Exploring the characteristics of professional learning communities in China: A mixed-method study. The Asia-Pacific Education Researcher, 25(1), 11-21. 